\title{
Communicative Competence and Cultural Emancipation: reviewing the rationale for educational studies in teacher education
}

\author{
PÁDRAIG HOGAN
}

ABSTRACT The numerous changes and improvements which have been wrought in teacher education courses in the last two decades have not, apparently, satisfied the critics. Ironically, the reverse seems to have occurred, as recent events on both sides of the Atlantic testify.

This essay argues that the developments of the last two decades in educational research and teacher education, which have yielded a wealth of new ideas and procedures, have also yielded a confusing proliferation of educational ideologies. In short, it suggests that the ascendancy of a diffuse, unselfcritical, and often combative discourse within educational studies has effectively eclipsed the more important question which must first be tackled if educational studies are to have a coherent, robust focus. This question, which is pursued in the second section of the paper, asks: is the educational enterprise, properly conceived, a distinctive, autonomous or sui generis enterprise with purposes of its own which are universal, or is it essentially a subservient enterprise, a vehicle for one or other currently prevailing ideology (cultural, technological, political, religious, etc.)? In exploring this question the essay puts to work some enduring insights from contemporary European philosophy, arguing that education as a 'practical hermeneutic discipline' holds a singular promise. Some important consequences of this promise for educational studies and teacher education are then considered.

\section{I: THE PROBLEM THAT WON'T GO AWAY: THE 'THEORY/PRACTICE' RIFT IN TEACHER EDUCATION}

We have been familiar for many years with the complaints of student teachers about the 'irrelevance of theory' in courses for the preparation of teachers. Although this issue has received regular attention in the various journals of education and has been addressed by a variety of measures in the design of courses in recent years, the problem still persists. Indeed, its refusal to go away remains a public source of embarrassment where the credibility of educational studies is concerned. From a review of the literature on the matter, perhaps the most notable critic of the so-called theory/practice rift has been Professor Edgar Stones (1979, 1981, 1983), while John Wilson of Oxford has also regularly addressed this issue in his numerous probing explorations of the field of educational studies (Wilson, 1975, 1982, 1983). Many others have taken up the issue in recent years from the perspective of critical social theory. These include Gitlin \& Teitelbaum (1983), Zeichner $(1983,1986)$ and Giroux \& McLaren (1986). 
Stones's criticisms in his 1983 review essay summarise in succinct if forthright terms the enduring difficulties of teacher education courses which give rise to the 'theory/ practice' rift. His criticisms are three-fold, and concern: (i) the 'theoretical' content of the courses; (ii) the methods of teaching and learning on the courses; and (iii) the nature of the relationship between schools and the education departments in centres of higher education. These criticisms, and Stones's suggestions for remedy, serve as an appropriate starting point for this review of the rationale for educational studies in teacher education courses.

In relation to the first of his three criticisms, namely, the content question, Stones argues for a shift away from 'attempts at encyclopaedic coverage of educational theory' and for a more deliberate focus on issues directly concerned with effective' pedagogy. This shift, he claims, would have important consequences for his second area of concern, the methods of teaching and learning employed in the preparation of teachers. In particular, it would remove the emphasis from a transmission style to a more participatory style of teaching and learning for both staff and students in centres of teacher education. Possibly anticipating objections to this from lecturing staff in education departments, Stones argues frankly that:

Staff inducting student teachers into the principles and practice of teaching by depending in the main on verbal transmission, declare by their actions either lack of faith in their expositions on the subject of human learning, or ignorance of a pedagogy that can help to enhance those kinds of learning that are typically human.

The chief obstacles to such participatory learning becoming the normal pattern in the preparation of teachers lie, in Stones's view, in established institutional practices and in the diverging attitudes on teacher preparation, between schools on the one hand, and centres of teacher education on the other. In this, his third area of criticism, Stones describes the differences between campus and school in the following terms:

Both institutional structures and psychological attitudes conspire to tear students in two. The schools treating them like surrogate teachers give them a programme as much like a 'real teacher's' as possible; while the training institutions give a very limited school-related theory but eventually pass judgement on the students in the final assessment ritual. In this process students get an education and training more like a dog's dinner than an intellectual feast.

The directness of attack employed by Stones in his argument may prompt many academics, and perhaps others who are constitutionally unsympathetic to this style of discourse, to make light of his position, or to overlook the fact that his concern is with fundamentals rather than with derivative issues-albeit currently topical issues. For instance, it might be charged against those who accept Stones's argument-and here I must include myself in important respects-that they fail to acknowledge the extent of the changes which have taken place in teacher education courses within the last two decades, and which have accelerated dramatically in both the United States and the United Kingdom in the last few years. Many of these changes, such as competency based, or performance based appraisal of student teachers, or new requirements for 'relevance' in the design of teacher education courses, originated in highly politicised contexts of North American-and more recently British-schooling. They originated, moreover, largely in response to demands coming from outside of educational circles. A growing demand among influential groups within the public for a more promptly 
measurable kind of accountability in schools and colleges is generally accepted as providing the main impetus for these developments.

Whatever its sources of impetus, the merits of the research of the last two decades on educational objectives, classroom management, teacher supervision, or assessment of performance, are considerable and enduring. Notwithstanding these benefits, however, or those of newly-developed studies of life within schools, we are unfortunately still scarcely closer than we were 20 years ago to a shared understanding of the more fundamental question of what the educational enterprise is essentially about, or, more significantly perhaps, what it is not about. In fact there are probably even more diverse views now than there were in the stormy sixties (albeit in a less 'newsworthy' manner) on this central question, and on the directly related question of how the purposes of teaching and learning should properly be understood. The rationale on which teacher education courses are based remains inadequate in basic respects until an answer in universal terms-even if a provisional answer-can be given to this question. How far we are at present from such an answer may be gleaned from a few summary reflections on current educational thought and action.

Is it not likely, for instance, that each or any of the following basic questions might still unleash an impassioned controversy in most educational discourse? (1) Is the educational enterprise, as Plato long ago insisted, essentially about the custodianship of institutionally established values (intellectual, moral, religious, political, etc.)? (2) Or is it, as the example of Socrates seems to suggest, essentially about an exploratory critique of such values? (3) Or is it, as the followers of Marx have proposed, about the overthrow and replacement of such values? (4) Is the business of teaching and learning, at the end of the day, a subtle (or not so subtle) battle for the minds and hearts of the young, carried out under unacknowledged conditions of violence? (5) Or is it a defensible cultural initiation carried out under justifiable conditions of restraint?

Questions such as these have not featured prominently in the prodigious research on teacher education in recent years-perhaps understandably so, as the kinds of dispute historically provoked by such questions have almost invariably proved to be futile. Yet in all educational enquiry, from the most traditional kinds of behaviourism to the most novel forms of action research, there remains decisively active in the researchers' basic orientations a network of preconceptions or assumptions where answers to questions of this kind are already prejudged, or taken for granted in one way or another. Moreover, issues such as the goals and style of educational management, the practical contexts of 'performance' or 'competency', the experienced quality of teaching and learning, to take but a few examples, uncover some of the more intractable difficulties within educational studies. Such issues can receive quite different, and even conflicting meanings, depending on how underlying questions, such as the five outlined above, have been already decided in the enduring beliefs and outlooks of researchers, lecturers, teachers, students, administrators, parents, interest groups and so on. For those professionally inolved in education, however, and in a special way for those whose responsibility lies mainly in the preparation of teachers, or in research into this field, it becomes in each instance a necessity, or indeed an imperative, to render this personal ideological underworld as transparent as possible to critical self-scrutiny in one's disciplined professional outlook.

Progress in the pursuit of this imperative would not, of course, finally rid teacher education, or the field of educational studies itself, from the problematic intermingling of personal world-views or interests with scholarship. Such progress might realistically expect, however, to make significant inroads in this direction and thus gradually to 
mark out a clearing where it would be possible to view teaching and learning as a singular kind of human communicative event; an event which-in the wide variety of contexts where it is attempted-might well be tough-minded or resolute as circumstances merit. But in any case, it is an event whose central business must remain the faithful bringing-to-presence for learners of the more imaginative and enduring of mankind's cultural accomplishments. This is, in the strictist sense, a non-partisan endeavour, and as such, it must seek to remain critically alert, emancipatory, and indeed fraternal, to a painstaking or scrupulous degree. We begin to uncover here a universal characteristic: something akin to an educational counterpart of the Hippocratic Oath. Insofar as personal 'values' have a justifiable place in the educational enterprise, it must be on such a universal foundation.

In the description of the educational enterprise which has just been given, a picture of a particular kind of professional discipline, or ethic, emerges rather strongly. It is important at this point to make secure our understanding of such an ethic, and of its foundations. In this task, which will be tackled in an introductory way in the next section, we might seek not only to set to work a dismantling of the 'theory/practice' dichotomy in teacher education, but also to open the way for a conception of educational studies and of pedagogy which might indeed be exemplary for all fruitful or enriching encounters with cultural tradition. Our efforts might also, in this respect (in the third section of this essay) serve to highlight the main obstacles to such fruitful learning; obstacles which perennially encumber the efforts of teachers, and the educational enterprise more generally. These obstacles include: (1) a wide range of psychological issues concerning the abilities and dispositions of pupils and teachers; (2) historical patterns in educational structures, procedures and attitudes; (3) sociological and anthropological characteristics which render cultural idioms tendentious and which inhibit mutual understanding; and not least (4) a widespread philosophical ambiguity about pedagogy itself.

\section{II: TEACHING AND LEARNING AS A HERMENEUTIC DISCIPLINE}

Does Stones put the matter too strongly when he speaks of student teachers being 'torn apart' by the conflicting priorities of schools and the academies of teacher education? I suspect that many will think he does, that an alarmist attitude is evident here. Yet, if we place ourselves (or re-place ourselves) in the shoes of the student teacher on a conventional teacher education course and attempt, even briefly, to reconstruct his or her experienced world, at least three main sources of anxiety characteristically manifest themselves. First, there is the continual anxiety, while on teaching practice, to be a success in the classroom and to be accepted in the staffroom; or at least, not to make a mess of things in the classroom and thus be a pitiful figure in the staffroom. Secondly, there is the periodic anxiety, which invariably increases as the school and college year progresses, about one's supervisors' expectations-which might often simply not be achievable in one's school. Thirdly, there are anxieties about the assessments and examinations in the 'theoretical' areas of the course, which may sometimes seem quite remote from one's classroom concerns but which nevertheless loom ominously as examinations or assessment deadlines draw close.

Indeed, the bi-location of student teachers in settings which are often tenuously linked at best (school and campus), which frequently hold different views of learning, different conceptions of authority and even different assumptions on what the educational enterprise is basically about, may not merely be the source of periodic 
anxieties. More seriously, experiencing such different worlds may well disfigure, or even undermine, a student teacher's efforts to put together a coherent picture of his or her own identity as a teacher (see Helden, 1985; Vonk, 1983). Where one's emergent understanding of oneself as a teacher unfolds in such an ambiguous or unstable context it is hardly surprising if a degree of uncertainty, or of cynicism, takes root in this understanding and carries over into one's attitudes as a teacher. Such characteristics more than occasionally reveal themselves in more experienced teachers in an acquiescent, instrumental attitude towards examinations in general, or a severely pragmatic approach to teaching and learning, or a reluctance to handle weaker pupils, or a view of education and schooling coloured mainly by considerations of surviving or beating the system.

A point that emerges from the above arguments is that the 'theory/practice' rift in the experienced world of the student teacher is very often the natural outcome of a conflict of world views-particularly institutionalised world views-concerning the nature of the educational enterprise itself. The roots of the difficulty, as we have seen, lie deeper than in the arena of ideological or power conflicts. They lie rather in the failure, or inability, of educational research to provide to date, a coherent account of, and a compelling rationale for, what the educational enterprise is essentially about, and, equally important, what it is not about. Thus, despite the progress of educational research on matters such as the effectiveness aspects of teaching and the performative aspects of learning, there is as yet no universal standard among educators by which we might properly distinguish acts of teaching and learning which are genuinely educational from those which are not.

Against this rather pessimistic conclusion many school authorities, and also many academics who are concerned with the preparation of teachers, might assert that there is a broad consensus in society at large, and one which is reflected in the work of both school and campus, that the general goal of education is the transmission of the 'cultural heritage' and 'values' of society to the younger generations; or, more formally perhaps, the initiation of younger generations into intrinsically worthwhile activities. Notwithstanding the general currency of goals such as these, they beg a vast range of questions; questions which have more a political than an educational focus, including, for instance: who decides the worthwhileness or worthlessness of an activity? whose culture and whose 'values' get represented in 'cultural heritage', and whose do not? And even assuming for the sake of argument the happy event of agreement in this normally contentious arena, the more significant educational question still remains unasked: what happens to 'cultural heritage' and to 'values' when translated into curricular and examination mechanisms of an education system? or when experienced by teachers through the school managerial and administrative structures? or by pupils through the various pedagogical styles of schools and colleges?

Let us explore the landscape uncovered by these questions by noting from the start that the intermittent wranglings of interest groups and the continual distortions in communicative experience which occur within the context just mentioned should not occasion us to abandon all talk of 'cultural heritage' as simply rhetorical or fanciful. (The history of education is replete with examples of such wranglings and distortions, and these are worthy of study by all students of teaching.) Our everyday experience as humans is invariably pervaded in any case by cultural influences and by traditions which have become institutionalised in our relations with one another. But it does not follow that we are necessarily or blindly conditioned in all our thoughts and actions by the influences of authority and tradition, or by the overlooked cultural biases which 


\section{Oxford Review of Education}

have become lodged in our deeper beliefs and outlooks. More especially, it does not follow that the distortions and blindspots in cultural traditions must invariably get reproduced through the work of schools and colleges.

The educational significance and promise of our standing within a context of cultural and historical traditions first comes home to us only when we properly grasp the following points, which summarise some of the most distinctive contributions of recent hermeneutic philosophy.

(1) Because of the historical and interpretative character of human understanding itself, we are all too often advocates or agents (or perhaps half-consciously victims) of those attitudes and outlooks which, as preconceptions, have quite naturally taken root in our experience hitherto.

(2) Much of this stream of cultural influences will continue to lie beyond the critical awareness of even the most logically proficient among us.

(3) Nevertheless, a potential critical interplay between the accomplishments and claims of cultural traditions on the one hand, and the emergent abilities and sensibilities of learners on the other, remains possible as one of mankind's most inviting and enriching pursuits.

The systematic study of this interpretative interplay itself describes the central concern of hermeneutics as a philosophical discipline. But the judicious bringing about of such an interplay in one's deliberate engagements with others is what sets education apart as a practical hermeneutic discipline. Thus, the hermeneutic character of experience which is properly educational is described by Gadamer as follows:

It is not only that historical tradition and the natural order of life constitute the unity of the world in which we live as human beings; the way that we experience one another, the way that we experience historical traditions, the way that we experience the natural givenness of our existence and of our world, constitutes a truly hermeneutic universe, in which we are not imprisoned, as if behind insurmountable barriers, but to which we are opened. (Gadamer, 1975)

For this openness to be grasped, however, to speak nothing of its being fruitfully availed of for educational purposes, the spontaneous interpretations and judgements which accumulate in our everyday lives, and which constitute our understanding of ourselves and of our experienced world, must be thoroughly subjected to critical scrutiny. That is to say, the continuous stream of interpretation within each of us must become self-reflective, and in a disciplined manner. In a word, it must become hermeneutic. Pursuing a little further the implications of Gadamer's point, the picture of the educational enterprise which begins to take shape here is not that of any kind of contest between interest groups or 'value' positions, but rather a universal species of intercourse with its own character and dignity. Education as a practical hermeneutics can thus be seen as a sui generis enterprise, rather than as a vehicle for advancing the interests of one or other 'ism'.

Already the import for teacher education, and for educational studies, of education as a hermeneutic discipline begins to suggest itself, particularly in the 'universal', 'selfcritical', 'interpretative' and 'interplay' motifs and not least in the radically new context for the uncovering of personal identity which emerges here. By way of a short elucidation of this hermeneutic concept of education, it is worth considering it in connection with the moral context of the kind of communicative event we have been 
just examining. Perhaps this can best be done by considering briefly two possible objections which might be brought against the conception of education as hermeneutic.

On the one hand, the objection might be made that the communicative event described seeks to be ideologically or morally neutral, but that, as no kind of human intercourse is without influential moral orientations, the kind of interplay being envisaged is an illusion, or a spurious moral utopia. On the other hand, it might be objected that since tradition, in its wide variety of distorted, or ideological manifestations will be facilitated, or even invited in this interplay, the most likely outcome will be moral relativism, or anarchy. It is of course inevitable that attitudes and outlooks - towards the subject or tradition of study, towards the teacher, towards others, etc. - will be continually 'picked up' in a classroom. What the above objections fail to recognise, however, is that such 'picking up' is generally influenced much more by how things are handled in the classroom than by the authorised contents of a syllabus. It is noteworthy then that both objections-the utopian and the relativistic-overlook the same thing, namely the presence of the teacher, or more precisely, the central importance of the teacher's self-understanding to the kind of communication which is to be undertaken and to the kind of climate, or ethos, which is thus to be brought into being.

This ethos, or moral climate, does not have its philosophical origins in Gadamer's hermeneutics, nor in any other modern or contemporary philosophical writings. Rather, as an exemplary kind of pedagogical ethos, its origins lie in the actual educational work of Socrates with the young students of Athens. Far from being morally neutral, the ethos of the Socratic seminars was, characteristically, both selfcritical and adventurous. So far as we can gather, moreover, this ethos was fraternal in a universal sense. In this kind of teaching and learning, viewpoints from all quarters might properly expect a critical, yet a genuine and a generous engagement. No sectional viewpoint, however, could expect an exclusive or institutionally privileged hearing. In this sense, only those in the grip of a sectional creed would have anything to fear from such an ethos, or from such a universal characterisation of education. A proper grasp of this point is crucial if the heart of the educational enterprise is in any realistic sense to be put beyond the reach of the strategic concerns of ideology.

Perhaps one of the more enduring ironies in the history of Western education lies in the decisive eclipse of this Socratic conception of communicative openness; its displacement from educational tradition by the seminal, but often tendentious spirit of the middle and later writings of Socrates's greatest disciple, Plato. (See Plato's Republic and his Laws. See also Popper, 1966.) Not with Rousseau, or Froebel, or Dewey, nor with the so-called 'progressive' tradition in education-indeed not till the recent hermeneutics of Gadamer and Ricoeur, and, in a different way, the formal and empirical pragmatics of Habermas-has the Socratic conception of communication, as an emancipatory concern with tradition and emergent identity, resurfaced in a compelling manner in the broader Western tradition of thought and discourse. These recent intellectual developments now hold a singular promise for our understanding of education as a sui generis, and a non-partisan enterprise.

\section{III: CULTURAL AND COMMUNICATIVE INSIGHT: EDUCATIONAL STUD- IES AND THE SELF-UNDERSTANDING OF THE TEACHER}

Despite the prevalence of sectional interests and of proselytising designs on the sensibilities of the young in the history of education, it would be rash to conclude that 


\section{Oxford Review of Education}

the eclipse mentioned above marks a virtual absence of emanicipatory learning in schools or colleges throughout the ages, or in the immense variety of cultural and communicative settings in which educational ventures have been undertaken since the age of the Greeks. In the history of the West, however, the conduct of education has characteristically - or institutionally-been viewed under the banner of one or other 'ism', whether religious, secular, political, economic, technological, or other in origin. Indeed, in the present day, not least because of the vexed history of the subject, it is very difficult to rescue our understanding of education from the idea that it must ultimately be seen as a vehicle for the transmission of one or other preferred assemblage of values, skills and outlooks.

The task of undertaking this 'rescue' thus becomes a central and most thoughtworthy responsibility of educational philosophy. In other words, prior to any consideration of the three areas marked out for attention by Stones at the beginning, the more basic task is that of elucidating and clarifying the context of teacher education in such a way that it seeks to be itself an exemplary kind of discourse: the practical embodiment of what Habermas calls an 'ideal speech community'. Habermas himself describes this event as follows.

Imagine individuals being socialised as members of such an ideal community; they would be acquiring identities with two complementary aspects: the universal and the particular. On the one hand... they would learn to orient themselves within a universalistic framework, that is, to act autonomously (in Kant's sense); on the other hand they would learn to use this autonomy-which makes them equal to every other morally acting subject-in order to develop themselves in their subjectivity and uniqueness. (Habermas, 1984)

The undeniably Socratic note here is taken up and made more explicit by Thomas McCarthy, Habermas's translator, in the following comment on the passage just quoted. He emphasises that Habermas is attempting to pin down 'a notion of ego identity that centres around the ability to realise oneself under conditions of communicatively shared intersubjectivity'. Clearly, in educational contexts which are highly bureaucratised, systematised, or indeed authoritarian, 'communicatively shared intersubjectivity' is unlikely to happen or come about simply by placing teachers and pupils in a room with an authorised syllabus to follow. The enduring lesson to be gathered (though in different ways) from the seminal works of writers such as Habermas, Gadamer and Ricoeur, is that an emancipatory relation to tradition is something which must continually be won through the painstaking skill, insight and judgement of someone who is well versed and well trained in a critical hermeneutic discipline. With this goes the realisation that even when achieved, this practical bringing-into-relation of students with a tradition or subject of learning is continually threatened from many sides: by well-meaning crusaders for a particular viewpoint or cause, by the bureaucratic imperatives of educational systems, and not least by the continual ad hoc demands which arise from 'vehicle' conceptions of education in society at large.

Perhaps we can profitably proceed now from the underlying context of teacher education and educational studies to (1) the content of such studies; (2) the distinctive method, or style of study which is called for; and (3) the organisation of teacher education courses between the different kinds of institutions (i.e. campus and school) where such courses are generally located. We shall treat the 'content' question in the remainder of this section and pick up the other two in the final section. In relation to 
the 'content' issue. Stones, as we have seen, has suggested that a deliberate focus on pedagogy should become the heart of teacher education. Where pedagogy is understood, however, mainly in the restricted sense of 'how to teach', or in terms of study of principles of effective teaching, there is every likelihood-even an inevitability-that its importance will be viewed chiefly in a strategic light: as a device to maximise the effectiveness of the 'vehicle' which is to advance the interests of a particular party or 'world-view'.

The moral context, or identity-forming context, which-as we have also seen-is a central feature of any pedagogical event, tends to get overlooked, or to be taken for granted in this narrower conception of pedagogy. A broader conception of pedagogy, one which is concerned with the cultural and emanicipatory features of communicative action, in addition to the effectiveness of this action, is clearly called for here. Without such a wider and more probing concept of pedagogy the teacher's understanding of himself or herself, remains deficient in fundamental respects. The corollary of this is that a more inclusive concept of pedagogy is central to securing an adequate grasp of the enterprise of teacher education.

Far from being irrelevant, the traditional disciplines of educational studies have a decisive and thought-worthy part to play in this enterprise; notwithstanding the new educational wisdom in more than one country which is somewhat scornful of these disciplines. When they are adequately conceived and practised, the traditional disciplines of education provide a crucial range of insights into the bringing-about of that interplay which we have described as the practical work of the teacher. Only an introductory survey of these disciplines is possible here, but even within such an outline, some fundamental points call for our attention.

First, where the contribution of educational psychology is concerned, developmental theories, learning theories, and pedagogical theories, now receive a more definite and more practical focus. They are now seen as playing a tributary role within a fuller psychology of human understanding (including misunderstanding and arrested understanding). Such an educational psychology, moreover, is properly viewed as complementary to the other disciplines of educational studies which seek to shed light on the singular features of the communicative event and the various features of the communicative context which need to be explored.

Secondly, sociological studies can, in like manner, illuminate the more important cultural, sub-cultural and class barriers to the interplay between pupils and the various vocabularies (or voices, to use Oakeshott's term) which seek to address them. An adequately conceived educational sociology can, further, tell us much about the kinds of idiomatic style, illocutionary patterns and pedagogical judgements which might best serve an emanicipatory cultural interest, especially in a wide variety of practical communicative contexts. Thirdly, the main business of the newer discipline of curriculum studies becomes that of a discerning, pedagogically guided review of cultural tradition in its wide range of voices (scientific, historical, religious, musical, mathematical, poetic, etc.). This includes keeping a critical eye on any voice which seeks an ascendancy over other voices, or which seeks an institutionalised privilege within the setting where teching and learning take place. It is worth emphasising again here the universal character of the educational enterprise, as both the sociology of education and curriculum studies have in recent years received particular attentions from the spirit of ideology.

Fourthly, historical and comparative studies, so often regarded as peripheral in teacher education courses, can now also be seen to bear directly on our theme. 


\section{Oxford Review of Education}

Properly viewed, these studies are concerned in a special way with the institutional aspects of the context of teaching and learning. By way of a wealth of examples they illustrate how the strategic actions of interest groups have variously distorted, or disfigured, or sometimes enriched, the milieu where encounters with cultural traditions are to take place. In this sense historical and comparative studies-involving well chosen research projects by students of teaching-become an effective disciplining of these students' own critical and interpretative abilities. This experience also roots more deeply their practical understanding of their work and gives perspective on the kinds of forces which invariably press from the outside on the context of teaching and learning. Without such a discipline the pitfalls of naive idealism lurk everywhere in the path of authentic pedagogical endeavour.

Fifthly, in relation to educational philosophy, we have already noted briefly that its central business includes that of rescuing educational discourse from the tendentious arena of 'isms'. But we must also include here the equally important task which this 'rescue' serves to make more possible and more inviting. That task is: the elucidation, clarification and safeguarding of education as a singular species of human intercourse. In this connection it has been suggested that the philosophical conception of education as a hermeneutic enterprise is a particularly promising one: that it underlines the universal and emancipatory, interpretative and self-critical character of an appropriately achieved interplay with the different vocabularies of cultural tradition. An alertness to this 'singular species' of human intercourse has thus been the guiding point for our brief exploration of how the traditional disciplines of education might become the informing context of student teachers' practical understanding of themselves and their work.

Finally, the recent discrediting of the 'disciplines' conception of educational studies, particularly in reviews of teacher education in the USA, England and Wales, betokens something more serious than can be explained by a swing 'back to basics' in educational ideology. The more serious point which we must acknowledge, however difficult such an acknowledgement may initially be, is that the field of educational studies has suffered from a malaise of uncertainty about itself for many decades and that this malaise became more public with the rapid expansions in teacher education during the seventies. The notable advances which were undoubtedly made in educational research over the last two decades thus lacked a compelling philosophical context (a coherent 'paradigm' in a different vocabulary) within which these advances themselves might take root. All too often the more prominent tendency was that of a number of separate disciplines somehow failing to concentrate their focus on the distinctiveness of educational experience, and seeking instead the respectability of a 'parent' discipline, or the protection of a currently fashionable trend in the social sciences. Wilson and Stones, in their different ways, have been to the forefront of a minority of writers who continually called attention to the unhealthiness of this state of affairs.

One enduring lesson to be learned from the recent crisis in teacher education is that it matters less what the various elements of educational studies are called (disciplinary 'purity' being among the more dubious of campus virtues) than that the field of educational studies is itself properly conceived and that the range of insights which these elements can then yield to our understanding is availed of in the most coherent, rigorous, and collaborative manner. To the two remaining issues in this endeavour we now turn in the final section of this essay. 


\section{IV: CULTURAL AND COMMUNICATIVE ACTION: THE FUSION OF INSIGHT AND SKILL}

In our discussion of the content of educational studies in teacher eduction we have dealt so far mainly with matters of insight rather than with matters of skill. We can take up the relationship of insight to skill now in dealing with the second and third areas outlined at the beginning, namely the methods, organisation and style of study in teacher education courses, and finally, the question of relations between school and campus. Here our observations will be brief as they are largely foreshadowed in what has been argued already. That teacher education should, as much as possible, be based on a participatory style of teaching and learning is a suggestion which has run throughout this essay. From the point of view of the organisation of teaching and learning, however, what is important is that such a participatory approach should be the unifying feature, or link, between the student teachers' encounters with educational studies, their studies of teaching methodology, their skill-based courses such as microteaching, and not least, their experience in school classrooms and staffrooms.

A carefully thought-out course in microteaching, when coupled with the use of interaction analysis by student teachers for self-evaluation purposes, provides a good example of how such integration can be initiated in a practical sense (Uí Chatháin, 1985) [1]. In such a situation, even the more reticent kind of student teacher has little serious alternative but to take an active and responsible hand in his or her own learning. This involves the cultivation among student teachers of an attitude of constructive criticism towards their own teaching; a practice which also has beneficial effects when it comes to the student teachers' relations with their supervisors. I have attempted to explore this rather complex issue elsewhere (Hogan, 1983), but it is worth mentioning the matter briefly here to emphasise that participatory learning by student teachers has decisive productive implications for the supervision of their teaching-an area where too often they have stood in silent fear and trembling when a supervisor calls.

Where the discipline of participatory learning gets underway in the skill-based areas of teacher education programmes, its extension to other areas of the programmes, where skill characteristically blends with insight, is a relatively uncomplicated matter. Methods courses in the various subjects on the school syllabus serve as a good example here. Transmission-type courses in subject teaching methods continually invite the risk of adopting a 'one right way' approach to the teaching of a subject. Even where the lecturer wishes to discourage a 'one right way' mentality, the anxieties which student teachers bring with them to these sessions from their classrooms, together with the lack of opportunity to address these anxieties in a lecture format, ironically make the demand for the 'one right way' a more pressing one among the student teachers.

A methods course which is from the start, however, based largely on a representative selection of teaching difficulties, as experienced and reported by student teachers themselves (see Busch, 1982; Hogan, 1982), offers perhaps the best opportunity for exploring alternative ways of tackling obstacles and for making an experience of the subject a revelatory and an emancipatory event for pupils and student teachers alike. In achieving this kind of self-disclosure moreover, such an event has the additional consequence of changing the nature of the student teacher's relationship to the subject in question. The student teacher begins, however hesitantly at first, to experience a hermeneutic relation to the subject. In other words, the subject, from being primarily an academic body of knowledge, or a programme-to-be-covered from a textbook, also 


\section{Oxford Review of Education}

emerges as an active voice which seeks to address the pupils through the living idiom which the student teacher now begins to discover and work out; thereafter to become, as a mature teacher, both fluent and resourceful in the idiom itself.

The schools where this rather vulnerable venture must be continually attempted often operate in contexts where communicative action tends to be bureaucratic, or strategic (in the sense already described). For this reason it is not merely desirable, but indeed essential, that contact between schools and centres of teacher education is frequent and reciprocal. From a network of enduring contacts with interested schools or teachers, centres of teacher education can involve teachers more actively in the ideas and activities which are best considered to advance educational thinking and to enrich educational practice. Thus, there can be a shared monitoring and appraisal of the various demands and interests which continually encroach on the communicative arena of education, and which, more than occasionally, effectively colonise this arena. Such networks are crucial if teacher education courses are to provide a realistic opportunity for the student teachers to become practically trained, as well as intellectually versed, in that hermeneutic discipline referred to at many points earlier.

Schools, for their part, and more particularly individual teachers, can profitably avail themselves of such networks, and not only to put their work with student teachers on a more secure and more satisfactory basis. More significantly perhaps, from the schools' and the teachers' standpoints, networks of this kind can be utilised by school principals and teachers to enhance the quality of in-service programmes, to identify and research educational matters in a distinctly educational forum, to strengthen and enrich their perspectives of their own work and thus, not least, to be able to forestall in some realistic measure the pervasive and disempowering effects of large educational bureaucracies.

\section{CONCLUSION}

Throughout this last section on the skill aspects and organisational principles of teacher education courses, our focus has remained, as it did throughout, on the unique interplay which is born of the cultural self-understanding and the communicative selfunderstanding of the teacher-except that in this final section we included the teacher not merely as student, but also as school staff member and as school principal, in our considerations. The major advantage in making this focus on self-understanding the heart of teacher education (pre-service and in-service) is that the teacher as learner is challenged from the start to tackle in a serious and enduring manner the question of his or her own identity as an educator. By contrast, the tendency of the effects of the more conventional and transmission-based courses of teacher education to become 'washed out' by a few years' experience in schools has often been noted. Perhaps the most noticeable consequence of such 'wash out' effects is that teachers become, by their own efforts, quite adroit at handling the various pressures of a politicised or bureaucratised work place. The more unfortunate consequence, however, is that all too frequently, teachers become quite at home in this milieu. In such circumstances it should hardly surprise us if the universal or emancipatory voice should become overshadowed or disfigured in educational discourse, or that power should thus gather itself into quarters where the discipline of self-criticism is virtually unknown.

Correspondence: Pádraig Hogan, Department of Education, St Patrick's College, Maynooth, Co. Kildare, Ireland. 


\section{NOTE}

[1] This kind of integration was initiated some years ago on our own Higher Diploma in Education course (one year post-graduation course) in Maynooth, and has been favourably reported on by the student teachers each year (see Uí Chatháin, 1985, below).

\section{REFERENCES}

Busch, F.W. (1982) The 'one-phase' approach to teacher education in West Germany, European fournal of Teacher Education, 5, pp. 169-177.

Gadamer, H.-G. (1975) Truth and Method (Trans. by G. Barden \& J. Cumming) (London, Sheed \& Ward).

Giroux, H. \& MCLAREN, P. (1986) Teacher education and the politics of engagement: the case for democratic schooling, Harvard Educational Review, 56, pp. 213-238.

Gitlin, A. \& Teitelbaum, K. (1983) Linking theory and practice: the use of ethnographic methodology by prospective teachers, fournal of Education for Teaching, 9, pp. 225-234.

Habermas, J. (1984) The Theory of Communicative Action: Vol. 1, Reason and the Rationalization of Society (Trans. by T. McCarthy) (Boston, Beacon Press).

Helden, H.J. van (1985) Lernen an Zwei Orten: Das Problem des 'Dualen System' in der Lehrerausbildung, European fournal of Teacher Education, 8, pp. 187-198.

Hogan, P. (1982) Teacher education and higher learning, Studies, 71, pp. 109-120.

Hogan, P. (1983) The central place of prejudice in the appraisal of student teachers, fournal of Education for Teaching, 9, pp. 30-45.

Popper, K. (1966) The Open Society and its Enemies: Volume 1: The Spell of Plato (London, Routledge \& Kegan Paul, originally published in 1945).

Stones, E. (1979) Psychopedagogy: psychological theory and the practice of teaching (London, Methuen).

STONES, E. (1981) Teacher education and pedagogy, fournal of Education for Teaching, 7, pp. 217-230.

StonEs, E. (1983) Perspectives in pedagogy, fournal of Education for Teaching, 9, pp. 68-76.

VoNk, J.H.C. (1983) Problems of the beginning teacher, European fournal of Teacher Education, 6, pp. 133-150.

Uí Chatháin, M. (1985) Microteaching, classroom interaction analysis and teacher self-evaluation: developments in the Higher Diploma in Education course at Maynooth, Irish Educational Studies, 5, pp. 198-217.

Wilson, J. (1975) Educational Theory and the Preparation of Teachers (Slough, National Foundation for Educational Research).

Wilson, J. (1982) The credibility of educational studies, Oxford Review of Education, 8, pp. 3-19.

Wilson, J. \& Cowell, B. (1983) Making educational studies respectable, European fournal of Teacher Education, 6, pp. 7-15.

ZEICHNER, K. (1983) Alternative paradigms of teacher education, fournal of Teacher Education, 34 (3), pp. 3-9. 